\title{
Middle Neoproterozoic syn-rifting volcanic rocks in Guangfeng, South China: petrogenesis and tectonic significance
}

\author{
WU-XIAN LI*, XIAN-HUA LI*† \& ZHENG-XIANG LI \\ *Key Laboratory of Isotope Geochronology and Geochemistry, Guangzhou Institute of Geochemistry, Chinese \\ Academy of Sciences, Guangzhou 510640, China \\ $†$ State Key Laboratory of Lithospheric Evolution, Institute of Geology and Geophysics, Chinese Academy of Sciences, \\ Beijing 100029, China \\ †Institute of Geoscience Research, Department of Applied Geology, Curtin University of Technology, GPO Box U1987, \\ Perth, WA 6845, Australia
}

(Received 22 May 2007; accepted 23 July 2007; First published online 8 April 2008)

\begin{abstract}
Middle Neoproterozoic igneous rocks are widespread in South China, but their petrogenesis and tectonic implications are still highly controversial. The Guangfeng middle Neoproterozoic volcanisedimentary succession was developed on a rare Sibaoan metamorphic basement (the Tianli Schists) in the southeastern Yangtze Block, South China. This paper reports geochronological, geochemical and $\mathrm{Nd}$ isotopic data for the volcanic rocks in this succession. The volcanic rocks consist of alkaline basalts, andesites and peraluminous rhyolites. SHRIMP U-Pb zircon age determinations indicate that they were erupted at $827 \pm 14 \mathrm{Ma}$, coeval with a widespread episode of anorogenic magmatism in South China. Despite showing $\mathrm{Nb}-\mathrm{Ta}$ depletion relative to $\mathrm{La}$ and $\mathrm{Th}$, the alkaline basalts are characterized by highly positive $\varepsilon \mathrm{Nd}(\mathrm{T})$ values $(+3.1$ to +6.0$)$, relatively high $\mathrm{TiO}_{2}$ and $\mathrm{Nb}$ contents and high $\mathrm{Zr} / \mathrm{Y}$ and super-chondritic $\mathrm{Nb} / \mathrm{Ta}$ ratios, suggesting their derivation from a slab melt-metasomatized subcontinental lithospheric mantle source in an intracontinental rifting setting. The andesites have significantly negative $\varepsilon \mathrm{Nd}(\mathrm{T})$ values ( -9.3 to -11.1$)$ and a wide range of $\mathrm{SiO}_{2}$ contents $(57.6-65.6 \%)$. They were likely generated by the mixing of fractionated basaltic melts with felsic melts derived from the Archaean metasedimentary rocks in the middle to lower crust. The rhyolites are highly siliceous and peraluminous. They are characterized by depletion in $\mathrm{Nb}, \mathrm{Ta}, \mathrm{Sr}, \mathrm{P}$ and $\mathrm{Ti}$ and relatively high $\varepsilon \mathrm{Nd}(\mathrm{T})$ values $(-3.0$ to -4.8$)$, broadly similar to those of the adjacent $c$. 820 Ma peraluminous granitoids derived from the Mesoproterozoic to earliest Neoproterozoic sedimentary source at relatively shallow levels. We conclude that the Guangfeng volcanic suite is a magmatic response of variant levels of continental lithosphere (including lithospheric mantle and the lower-middle to upper crust) to the middle Neoproterozoic intracontinental rifting possibly caused by mantle plume activity.
\end{abstract}

Keywords: Neoproterozoic, geochemistry, volcanic rocks, rift basin, South China.

\section{Introduction}

Middle Neoproterozoic igneous rocks are widespread in South China (Fig. 1a), but their petrogenesis and tectonic implications are still hotly debated (e.g. Li et al. 1999, 2002a, 2003a,b, 2006; Li, Li \& Li, 2005; Zhou et al. 2002b,c, 2006a,b; Wang et al. 2004, 2006). Based on similarities between the c. $820 \mathrm{Ma}$ mafic dykes and sills in South China and the coeval, plume-related Gairdner Dyke Swarm in Australia (Zhao, Malcolm \& Korsch, 1994; Wingate et al. 1998), and the presence of same-aged granitic intrusions (Li, 1999) accompanied by continental-scale doming and unroofing, Li et al. (1999) proposed that a c. $825 \mathrm{Ma}$ mantle plume beneath South China triggered the continental rifting and eventually led to the breakup of Rodinia. Recently, these authors further demonstrated that two episodes of widespread bimodal magmatism occurred at $c$. 830 $795 \mathrm{Ma}$ and c. 780-745 Ma, respectively, in South

$\dagger$ † Author for corresponence: lixh@gig.ac.cn
China; these age patterns are similar to those of middle Neoproterozoic bimodal magmatism in numerous other Rodinian continental blocks such as Australia, India, Madagascar, Seychelles, southern Africa and Laurentia (Li et al. $2003 b$ and references therein). Such globally widespread magmatism requires a large and sustained heat source, which Li et al. (2003b) suggested as reflecting the presence of a mantle superplume beneath Rodinia that led to the break-up of the supercontinent in the Neoproterozoic. In addition, these workers also argued that the Yangtze and Cathaysia blocks amalgamated to form the coherent South China Block during the Sibao orogenesis at c. 1.1-0.9 Ga (e.g. Li et al. 2002b, 2006, 2007c; Greentree et al. 2006; Li \& Li, 2003; Ye et al. 2007), thus precluding the occurrence of any 860-740 Ma magmatic arc in the interior of the South China Block.

Zhou and co-workers (e.g. Zhou et al. 2002b,c, $2006 a, b)$, on the other hand, interpreted the 860 $760 \mathrm{Ma}$ magmatic rocks as products of subduction around the Yangtze Block, a part of the South China 

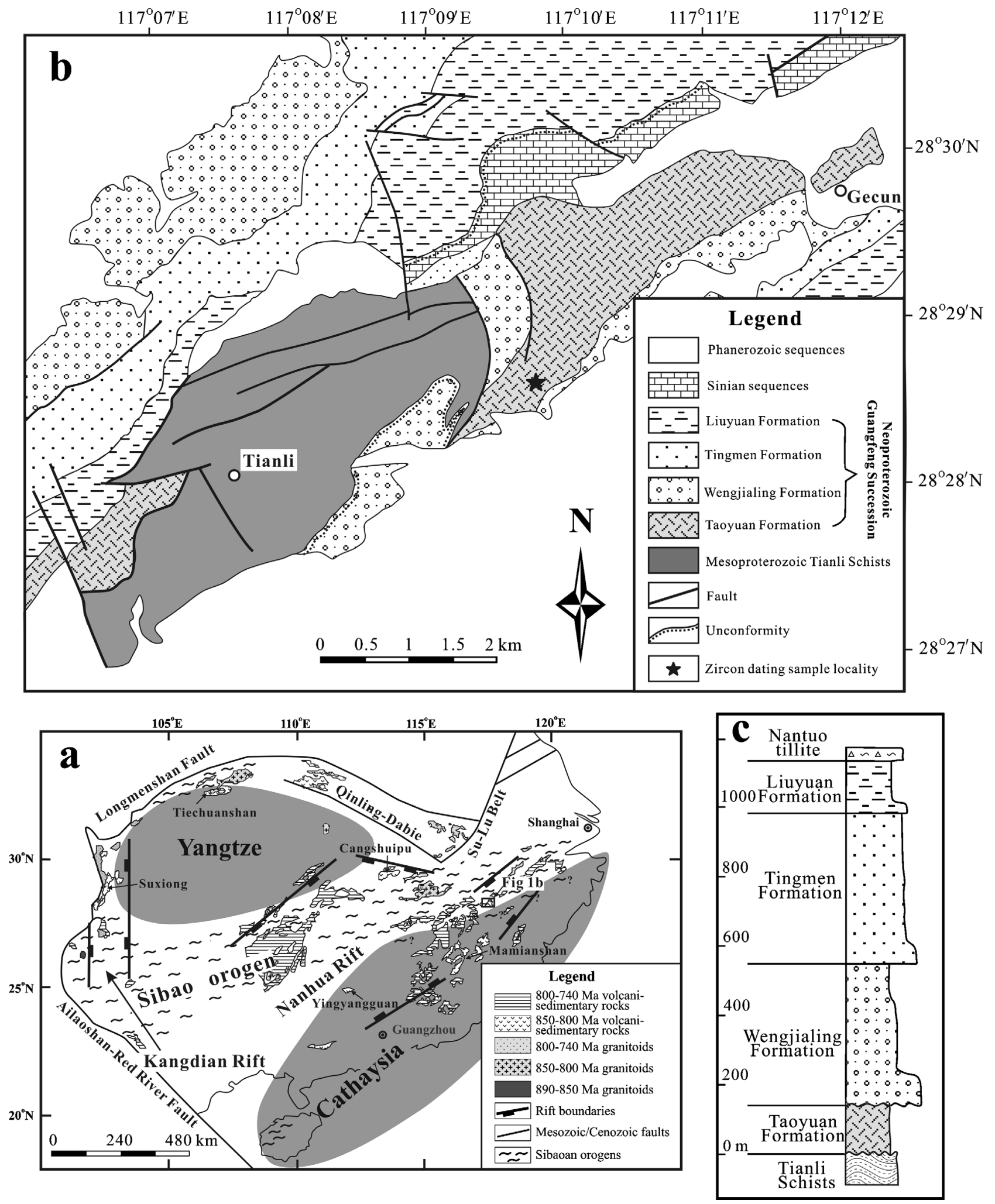

Figure 1. (a) Neoproterozoic rift basin, Sibaoan Orogen and distribution of magmatic rocks in South China (modified after Li et al. 2002b, 2003b; Wang \& Li, 2003), (b) Geological map of the Guangfeng region (modified after the 1:50 000 geological map), and (c) Neoproterozoic stratigraphic column of Guangfeng region (after Li et al. 2003c).

Block. In their model, the South China Block was either an isolated continent, or was located on the periphery of Rodinia during Neoproterozoic times. Others interpreted some of the $c .820-800$ Ma granitic rocks as products related to the continental collision between the Yangtze and Cathaysia blocks or postcollisional extensional collapse (e.g. Wang et al. 2006; $\mathrm{Wu}$ et al. 2006), rather than the products of crustal 
anatexis caused by conductive heating above a mantle plume (Li et al. 2003a).

The Neoproterozoic Guangfeng succession is located in the northern margin of the Northern Zhejiang sub-basin, part of the broader Nanhua basin (Fig. 1b) (Wang \& Li, 2003). The outcrop is a small (about $300 \mathrm{~km}^{2}$ ) but well-preserved Neoproterozoic volcanisedimentary succession (Wang \& Gao, 2003). Volcanic rocks occur at the bottom of the basin that overlies on the Mesoproterozoic Tianli Schists ( $\mathrm{Li}$ et al. 2007c) with a high-angle unconformity. Therefore, they were formed after the Sibaoan orogenesis. In this paper we report new SHRIMP U-Pb zircon ages and geochemical and $\mathrm{Nd}$ isotopic results of the volcanic rocks from the Guangfeng succession, with the aim of characterizing their petrogenesis and tectonic implications.

\section{Geological setting and petrography}

The South China Block is bounded by the QinlingDabie-Sulu orogenic belt to the north, the Longmenshan Fault to the northwest, and the Ailaoshan-Red River Fault to the southwest (Fig. 1a). It is generally believed to have been formed through amalgamation of the Yangtze and Cathaysia blocks. The oldest rocks in the Yangtze Block are the 3.2 to $2.9 \mathrm{Ga}$ Kongling complex (e.g. Qiu et al. 2000; Zhang et al. 2006a) occurring near the Yangtze Gorge. More recently, Zheng et al. (2006) and Zhang et al. (2006b) suggested that the Archaean to Palaeoproterozoic basement is probably widespread beneath the Yangtze Block. The oldest igneous rocks found in the Cathaysia Block are the c. $1.8 \mathrm{Ga}$ granite and metavolcanic rocks (e.g. Li, 1997; Li \& Li, 2007).

Neoproterozoic igneous rocks are widespread in South China, with most occurring in the Kangdian Rift (a SN-trending failed rift along the western Yangtze Block) and the Nanhua Rift (a broad, NE-trending rift basin between the southern Yangtze and northern Cathaysia blocks, Fig. 1a). They were floored unconformably by strongly deformed, late Mesoproterozoic to early Neoproterozoic successions and c. 825$820 \mathrm{Ma}$ granitoids that were exposed to the surface soon after emplacement due to rapid continental-scale doming and unroofing ( $\mathrm{Li}$, et al. 1999, 2003a,b; Wang $\& \mathrm{Li}, 2003)$. The Nanhua Rift can be further subdivided into three sub-rift basins, namely the Hunan-Guangxi sub-basin, the Jiangnan Ridge sub-basin and the Northern Zhejiang sub-basin (Wang \& Li, 2003). The Guangfeng succession is located at the northern margin of the Northern Zhejiang sub-basin along the southeastern margin of the Yangtze Block (Fig. 1a, b).

The Guangfeng succession consists of a basal conglomerate unit and volcanic rocks, and lacustrine, fluvial and littoral marine facies sedimentary rocks (Wang \& Gao, 2003; Li et al. 2003c). It is subdivided into four formations according to the petrological assemblages and sedimentological characteristics (Fig. 1c). They are, from bottom to top: (1) the Taoyuan Formation, consisting predominantly of volcanic and pyroclastic rocks that uncomfortably overlie the Mesoproterozoic Tianli Schists, (2) the Wenjialing Formation, comprising volcanic conglomerate overlying both the Tianli Schists and the Taoyuan Formation volcanic rocks, (3) the Tingmeng Formation, consisting of purplishred, thick-bedded to massive fluvial feldspathic litharenite, quartz feldspathic litharenite, siltstone and silty mudstone, and (4) the Liuyuan Formation, comprising thick-bedded pebbly quartz-sandstone with well-developed littoral marine cross-beddings. Overlying the Liuyuan Formation is the Nantuo glacial-marine deposits (tillite), which is a Marinoan-aged glaciation event dated at c. 600-630 Ma (Zhou et al. 2004). Two unpublished $\mathrm{U}-\mathrm{Pb}$ ages of $c$. $820 \mathrm{Ma}$ have previously been quoted for the andesite and rhyolite in the Taoyuan Formation (Zhang, Yan \& Yan, 1991; Wang \& Gao, 2003).

Volcanic rocks in the Taoyuan Formation include basaltic and andesitic rocks at the bottom of the formation, and felsic rocks mainly at the top of the formation, with an estimation of the basalt:andesite:rhyolite ratios being roughly 4:1:5 (Guan \& Yu, 1993). The basaltic rocks include porphyritic olivine basalts, which are dark-green in colour, containing sparse plagioclase and olivine phenocrysts, $0.7-1.5 \mathrm{~mm}$ in size. The olivine and plagioclase phenocrysts were altered to serpentine and carbonate, respectively. The groundmass of the basaltic rocks is aphanitic to microlitic (0.05$0.08 \mathrm{~mm}$ ), consisting of oligoclase/andesine, olivine, augite(?) and $\mathrm{Fe}-\mathrm{Ti}$ oxide with strong carbonation and chloritization alteration. The andesitic rocks are brick-red in colour, containing abundant (30-50\%) plagioclase and minor amounts of K-feldspar(?) and pyroxene(?) phenocrysts with variable grain sizes between $0.2 \mathrm{~mm}$ and $3 \mathrm{~mm}$. All phenocryst minerals were strongly altered. The groundmass of the andesitic rocks is microlitic, composed predominantly of plagioclase and sparse $\mathrm{Fe}-\mathrm{Ti}$ oxides, with most minerals being altered (carbonation and chlorization). The felsic rocks are light-grey in colour, containing sparse quartz, plagioclase and K-feldspar phenocrysts. The groundmass of the felsic rocks is aphitic to microlitic with weakly rhyotaxitic structure, consisting of quartz, plagioclase and $\mathrm{K}$-feldspar, and with variable degrees of sericitization.

\section{Analytical methods}

Zircons were separated using standard density and magnetic separation techniques. Zircon grains, together with zircon $\mathrm{U}-\mathrm{Pb}$ standard TEMORA, were cast in an epoxy mount, which was then polished to section the crystals in half for analysis. Zircons were documented with transmitted and reflected light micrographs and cathodoluminescence (CL) images as a guide to 
Table 1. SHRIMP U-Pb zircon data for Guangfeng rhyolite

\begin{tabular}{|c|c|c|c|c|c|c|c|c|c|c|c|c|}
\hline \multirow{2}{*}{$\frac{\text { Spot }}{1.1}$} & \multirow{2}{*}{$\begin{array}{c}\begin{array}{c}\mathrm{U} \\
(\mathrm{ppm})\end{array} \\
369\end{array}$} & \multirow{2}{*}{$\begin{array}{c}\begin{array}{c}\text { Th } \\
(\mathrm{ppm})\end{array} \\
240\end{array}$} & \multirow{2}{*}{$\frac{{ }^{232} \mathrm{Th} /{ }^{238} \mathrm{U}}{0.67}$} & \multirow{2}{*}{$\frac{f_{206 \%} \%}{0.98}$} & \multicolumn{2}{|c|}{${ }^{206} \mathrm{~Pb}^{* / 238} \mathrm{U}( \pm 1 \sigma)$} & \multicolumn{2}{|c|}{$\begin{array}{l}{ }^{207} \mathrm{~Pb} *{ }^{235} \mathrm{U} \\
\quad( \pm 1 \sigma)\end{array}$} & \multicolumn{2}{|c|}{$\begin{array}{c}{ }^{207} \mathrm{~Pb} *{ }^{206} \mathrm{~Pb} * \\
\quad( \pm 1 \sigma)\end{array}$} & \multicolumn{2}{|c|}{$\begin{array}{c}{ }^{206} \mathrm{~Pb} * \rho^{238} \mathrm{U} \\
\text { age (Ma) } \\
\quad( \pm 1 \sigma)\end{array}$} \\
\hline & & & & & 0.1333 & 0.0029 & 1.366 & 0.095 & 0.0743 & 0.0051 & 806.7 & 17 \\
\hline 2.1 & 174 & 133 & 0.79 & 0.55 & 0.1406 & 0.0034 & 1.286 & 0.054 & 0.0663 & 0.0026 & 848.2 & 19 \\
\hline 3.1 & 417 & 394 & 0.98 & 1.72 & 0.1412 & 0.0028 & 1.320 & 0.091 & 0.0678 & 0.0046 & 851.7 & 16 \\
\hline 4.1 & 338 & 168 & 0.51 & 1.88 & 0.1387 & 0.0029 & 1.243 & 0.075 & 0.0650 & 0.0038 & 837.2 & 17 \\
\hline 5.1 & 464 & 353 & 0.79 & 2.38 & 0.1335 & 0.0026 & 1.213 & 0.070 & 0.0659 & 0.0037 & 807.7 & 15 \\
\hline 6.1 & 561 & 425 & 0.78 & 3.25 & 0.1361 & 0.0026 & 1.293 & 0.079 & 0.0689 & 0.0041 & 822.4 & 15 \\
\hline 7.1 & 807 & 431 & 0.55 & 3.65 & 0.0776 & 0.0015 & 0.801 & 0.049 & 0.0749 & 0.0045 & 481.7 & 9 \\
\hline 8.1 & 201 & 118 & 0.61 & 1.96 & 0.1392 & 0.0034 & 1.537 & 0.086 & 0.0801 & 0.0043 & 840.0 & 19 \\
\hline 9.1 & 229 & 146 & 0.66 & 0.26 & 0.1421 & 0.0032 & 1.322 & 0.043 & 0.0675 & 0.0020 & 856.4 & 18 \\
\hline 10.1 & 746 & 669 & 0.93 & 4.48 & 0.1301 & 0.0027 & 1.317 & 0.152 & 0.0734 & 0.0084 & 788.4 & 16 \\
\hline 11.1 & 389 & 268 & 0.71 & 1.59 & 0.1348 & 0.0038 & 1.312 & 0.067 & 0.0706 & 0.0034 & 815.3 & 22 \\
\hline 12.1 & 239 & 136 & 0.59 & 0.38 & 0.1432 & 0.0046 & 1.333 & 0.072 & 0.0675 & 0.0034 & 862.9 & 26 \\
\hline 13.1 & 302 & 239 & 0.82 & 1.18 & 0.1302 & 0.0040 & 1.271 & 0.067 & 0.0708 & 0.0035 & 789.2 & 23 \\
\hline 14.1 & 244 & 158 & 0.67 & 0.35 & 0.1443 & 0.0045 & 1.328 & 0.062 & 0.0667 & 0.0028 & 869.1 & 25 \\
\hline 15.1 & 483 & 555 & 1.19 & 6.43 & 0.1229 & 0.0036 & 1.354 & 0.129 & 0.0799 & 0.0074 & 747.0 & 21 \\
\hline 16.1 & 542 & 432 & 0.82 & 1.77 & 0.1375 & 0.0037 & 1.417 & 0.064 & 0.0747 & 0.0031 & 830.5 & 21 \\
\hline
\end{tabular}

Data in this table were calculated after ${ }^{204} \mathrm{~Pb}$ corrections. The common $\mathrm{Pb}$ compositions were estimated from ${ }^{204} \mathrm{~Pb}$ counting, assuming an isotopic composition of Broken Hill lead related to surface contamination (Nelson, 1997). All errors are 1 sigma $(1 \sigma)$.

isotopic analytical spot selection and the mount was vacuum-coated with high-purity gold. U-Pb isotopic compositions were analysed by using the SHRIMP II ion microprobe at the Beijing SHRIMP Center, Chinese Academy of Geological Sciences. U-Th-Pb ratios were determined relative to the TEMORA standard zircon with ${ }^{206} \mathrm{~Pb} /{ }^{238} \mathrm{U}=0.0668$ corresponding to $417 \mathrm{Ma}$ (Black et al. 2003), and the absolute abundances were calibrated to the standard zircon SL13. Analyses of the TEMORA standard zircon were interspersed with those of unknown grains, following operating and data processing procedures similar to those described by Williams (1998). Measured compositions were corrected for common $\mathrm{Pb}$ using the ${ }^{204} \mathrm{~Pb}$-method, and an average crustal composition (Cumming \& Richards, 1975) appropriate to the age of the mineral was assumed. Uncertainties on individual analyses are reported at the $1 \sigma$ level, and mean ages for pooled ${ }^{206} \mathrm{~Pb} /{ }^{238} \mathrm{U}$ results are quoted at the $95 \%$ confidence level. U-Pb zircon data are listed in Table 1.

Because the basaltic and andesitic rocks are variably carbonatized, the rock powders were washed using dilute acetic acid to minimize the alteration effect before analyses. Major element oxides and trace elements were determined using a Rigaku ZSK100e XRF on fused glass beads and a Perkin-Elmer Sciex ELAN 6000 ICP-MS, respectively, at the Guangzhou Institute of Geochemistry, Chinese Academy of Sciences. Analytical procedures were similar to those described by Li et al. (2000, 2005). A mixture of $0.5 \mathrm{~g}$ powdered samples and $4 \mathrm{~g} \mathrm{Li}_{2} \mathrm{~B}_{4} \mathrm{O}_{7}$ was fused as a glass bead for $\mathrm{XRF}$ analysis. A loss-on-ignition (LOI) measurement was undertaken on samples of dried rock powder by heating in a pre-ignition silica crucible to $1000^{\circ} \mathrm{C}$ for one hour and recording the percentage weight loss. Analytical uncertainties of major elements are between $1 \%$ and $5 \%$. About 50 milligrams of each powdered sample were dissolved in a high-pressure Teflon bomb for 24 hours using a $\mathrm{HF}+\mathrm{HNO}_{3}$ mixture to ensure complete sample digestion. Rh was used as an internal standard to monitor signal drift during counting. The USGS standards BCR-1, BHVO-1, W-2, G-2 and GSP-1 were used for calibrating element concentrations of measured samples. Analytical precision is generally better than $3 \%$ for most trace elements.

The Nd fraction was separated by passing through cation columns followed by HDEHP columns. Nd isotopic compositions were determined using a Micromass Isoprobe multi-collector ICP-MS (MC-ICP-MS) at the Guangzhou Institute of Geochemistry. Analytical procedures were similar to those described by Li et al. (2004). Samples were taken up in $2 \% \mathrm{HNO}_{3}$, and the aqueous solutions were introduced into the MC-ICPMS using a Meinhard glass nebulizer with an uptake rate of $0.1 \mathrm{ml} /$ minute. The inlet system was washed out for five minutes between analyses using high-purity $5 \%$ $\mathrm{HNO}_{3}$, followed by a blank solution of $2 \% \mathrm{HNO}_{3}$, from which the sample solutions were prepared. The Isoprobe MC-ICPMS was operated in a static mode, and yielded ${ }^{143} \mathrm{Nd} /{ }^{144} \mathrm{Nd}=0.512125 \pm 11(2 \sigma)$ on 14 runs for the Shin Etsu JNdi-1 standard during this study. Measured ${ }^{143} \mathrm{Nd} /{ }^{144} \mathrm{Nd}$ ratios were normalized to ${ }^{146} \mathrm{Nd} /{ }^{144} \mathrm{Nd}=0.7219$. The reported ${ }^{143} \mathrm{Nd} /{ }^{144} \mathrm{Nd}$ ratios are adjusted relative to the Shin Etsu JNdi-1 standard of 0.512115 , corresponding to the La Jolla standard of 0.511860 (Tanaka et al. 2000).

\section{Results}

\section{4.a. SHRIMP U-Pb zircon age}

Sample 06GDB15-1 (28 $28^{\prime} 35^{\prime \prime} \mathrm{N}$; $\left.117^{\circ} 09^{\prime} 50^{\prime \prime} \mathrm{E}\right)$ is a rhyolite collected from the top of the Taoyuan Formation at the Shilong Reservoir. Zircon grains from 


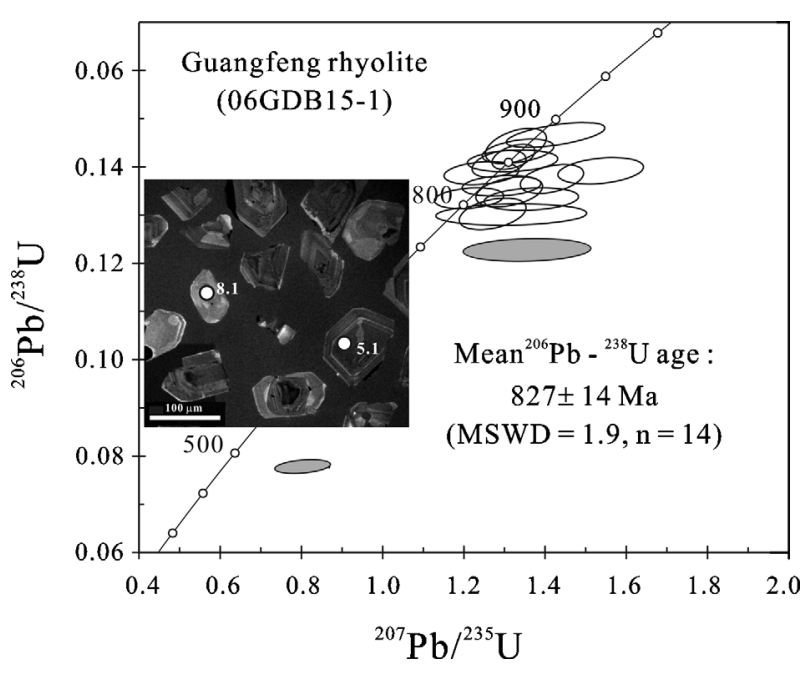

Figure 2. $\mathrm{U}-\mathrm{Pb}$ zircon concordia diagram for the Guangfeng rhyolite. Inset shows representative zircon CL images. Data not included in the calculated age for the sample are shown as greyfilled symbols.

this sample are mostly euhedral, ranging from 50 to $100 \mu \mathrm{m}$ in length, with length to width ratios of $1: 1$ to $2: 1$. They are relatively transparent and colourless, although a few are dark brown and turbid. Euhedral concentric zoning is common in most zircons under CL images and no inherited zircon cores were visible (Fig. 2 inset). Sixteen analyses of 16 zircons were obtained in sets of five scans during a single session (Table 1). They have highly variable abundance of $U$ (174-807 ppm) and Th (118-669 ppm). Th/U ratios vary between 0.51 and 1.19 , mostly clustering around $0.5-0.8$. Common $\mathrm{Pb}$ varies, with $f_{206}$ values falling in the range of $0.26 \%$ to $6.43 \%$. Apart from two analyses (spots 7.1 and 15.1) that are obviously discordant due to partial loss of radiogenic $\mathrm{Pb}$ (Fig. 2), the remaining 14 analyses gave ${ }^{206} \mathrm{~Pb} /{ }^{238} \mathrm{U}$ ratios indistinguishable within analytical errors, and their weighted mean yields an age of $827 \pm 14 \mathrm{Ma}$ ( $95 \%$ confidence interval). This age is interpreted as the best estimate of the formation age of sample 06GDB15-1.

\section{4.b. Major and trace element geochemistry}

Twenty Guangfeng volcanic rock samples were used for major and trace elements analyses. The results are listed in Table 2. Because all samples underwent varying degrees of alteration which might have modified the contents of mobile components (Romer, Forster \& Breitkreuz, 2001), the mobility of the major and trace elements needs to be evaluated. In general, zirconium, which is considered to be immobile during lowgrade alteration of mafic to intermediate igneous rocks (Gibson et al. 1982), has been plotted against some major and trace elements (Fig. 3). Although the basalts have highest LOI (loss of ignition) values of between $4.85 \%$ and $6.74 \%$, the high field-strength elements (HFSE: Nb, Ti, P, Th, Y and V) and rare earth elements
(REE) show fairly homogeneous geochemical compositions, indicating that these elements are generally immobile, whereas some large ion lithophile elements (LILE: $\mathrm{Sr}$ ) are mobile, as demonstrated by their obvious variations (Fig. 3). Similarly, the HFSE (Ti, P, Nb and $\mathrm{Th}$ ) and REE show close correlations with $\mathrm{Zr}$ for the andesitic and rhyolitic samples, implying that they are generally immobile. On the contrary, the LILE $(\mathrm{Sr}, \mathrm{Rb})$ and $\mathrm{V}$ are scattered, suggesting that they are probably mobile during alteration. Therefore, mainly the immobile elements, such as HFSE (Ti, P, Nb, Ta, Zr, Hf, Th, V) and REE, are used for further petrogenetic discussions.

The basaltic rocks are characteristically high in $\mathrm{TiO}_{2}$ (2.07-2.16\%), $\mathrm{P}_{2} \mathrm{O}_{5}(1.02-1.05 \%), \mathrm{Al}_{2} \mathrm{O}_{3}(17.12-$ $17.67 \%$ ) and $\mathrm{Nb} / \mathrm{Y}$ ratio of $0.86-0.92$, uniform in $\mathrm{SiO}_{2}$ (51-53.4\%) and low in $\mathrm{MgO}(2.2-3.5 \%)$, belonging to alkaline basalts. The andesitic rocks, on the other hand, have considerably higher and variable $\mathrm{SiO}_{2}$ (57.6-65.6\%), but lower $\mathrm{MgO}(0.49-0.70 \%)$ and $\mathrm{TiO}_{2}(0.84-1.21 \%)$, except for sample 03SC05-2 which has relatively high $\mathrm{MgO}(2.64 \%)$. The rhyolitic rocks are highly siliceous $\left(\mathrm{SiO}_{2}=74.3-76.6 \%\right)$ and peraluminous $(\mathrm{A} / \mathrm{CNK}>1.6)$. The three groups of volcanic rocks have different evolved trends in most $\mathrm{Zr}$ versus major and trace elements plots (Fig. 3, Table 2), especially in $\mathrm{Zr} v . \mathrm{TiO}_{2}, \mathrm{P}_{2} \mathrm{O}_{5}$, Th and $\mathrm{Nb}$ plots, suggesting that they are not cogenetic.

On the chondrite-normalized diagrams (Sun \& McDonough, 1989), all basaltic rocks have uniform and significant LREE-enriched patterns (Fig. 4a) with $\mathrm{La}_{\mathrm{N}} / \mathrm{Yb}_{\mathrm{N}}=17.6-21.2$, and slightly positive Eu anomalies $(\delta \mathrm{Eu}=1.1-1.2)$. Contrarily, the andesitic rocks have variable REE abundances and LREE-enriched patterns (Fig. 4b) with moderate Eu negative anomalies $(\delta \mathrm{Eu}=0.7-0.9)$. They are characterized by steeply right-inclined LREE patterns $\left(\mathrm{La}_{\mathrm{N}} / \mathrm{Sm}_{\mathrm{N}}=4.4-5.8\right)$ but gently right-inclined HREE patterns $\left(\mathrm{Gd}_{\mathrm{N}} / \mathrm{Yb}_{\mathrm{N}}=1.5-\right.$ 2.2). The rhyolitic rocks show uniform LREEenriched and MREE to HREE-flat patterns, with $\mathrm{La}_{\mathrm{N}} / \mathrm{Sm}_{\mathrm{N}}=5.1-6.0, \mathrm{Gd}_{\mathrm{N}} / \mathrm{Yb}_{\mathrm{N}} \approx 1.0$ and significant Eu negative anomalies $(\delta \mathrm{Eu}=0.50-0.55)$ (Fig. $4 \mathrm{c})$. It is noted that their REE patterns are strikingly similar to those of the regional c. 820 Ma peraluminous granitoids from southern Anhui and northern Jiangxi provinces (Li et al. 2003a; Wu et al. 2006).

On the primitive mantle-normalized trace element diagrams (Fig. 4d), the basaltic rocks show 'humped' patterns characterized by variable enrichments in most incompatible trace elements but depletions in $\mathrm{Nb}$ and $\mathrm{Ta}$ relative to neighbouring elements, resembling those of the Cenozoic extension-related basalts in the Basin and Range Province (e.g. Hawkesworth et al. 1995). The andesitic rocks are characterized by obvious $\mathrm{Nb}$ and $\mathrm{Ta}$ depletions relative to $\mathrm{La}$ and $\mathrm{Th}$, with $\mathrm{Nb} / \mathrm{La}=0.24$ 0.36 and $\mathrm{Nb} / \mathrm{Th}=0.87-1.01$. Their primitive mantlenormalized trace element patterns resemble that of the average middle crust (Fig. 4e). The rhyolitic rocks have 


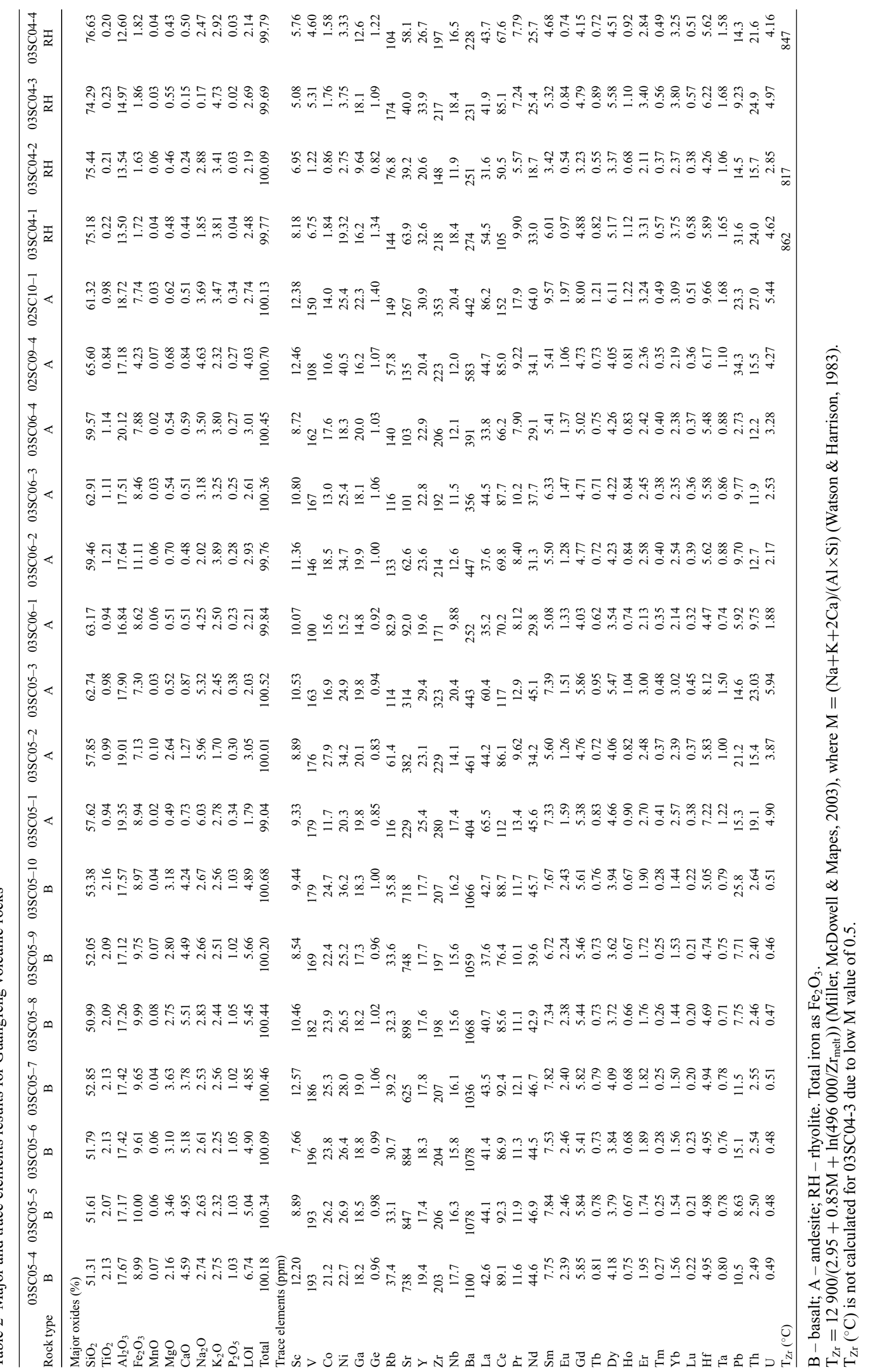



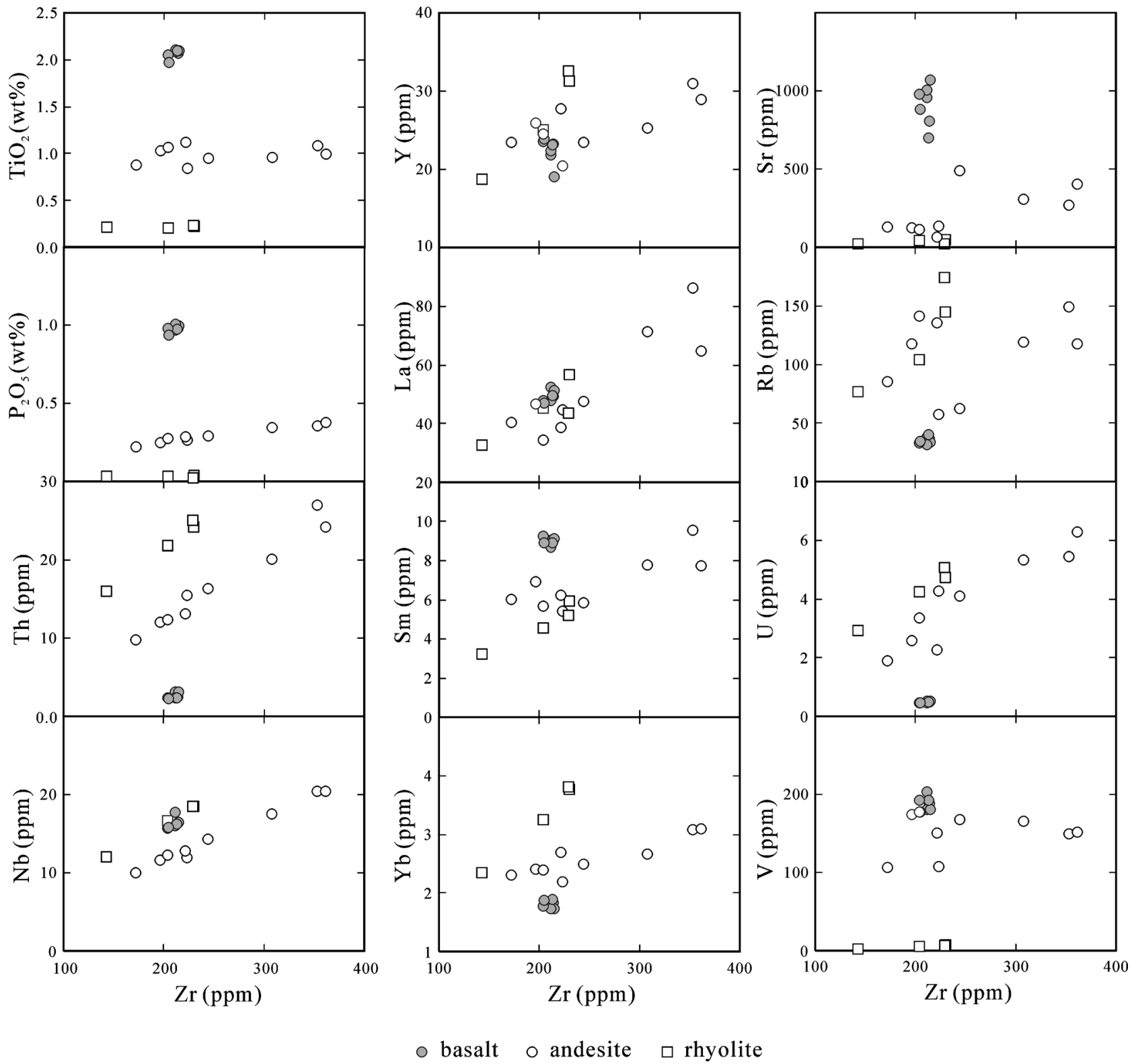

Figure 3. Plots of selected major and trace elements versus Zr.

strongly fractional patterns with significant depletions in $\mathrm{Nb}, \mathrm{Ta}, \mathrm{Sr}, \mathrm{P}$ and $\mathrm{Ti}$, due to fractional crystallization of plagioclase, apatite and $\mathrm{Fe}-\mathrm{Ti}$ oxides, or as residual minerals in the source (Fig. 4f). Their patterns are similar to those of the average upper crust and the regional c. $820 \mathrm{Ma}$ peraluminous granitoids (Li et al. 2003a; Wu et al. 2006).

\section{4.c. Nd isotopes}

Eleven samples were selected for $\mathrm{Nd}$ isotope analyses, including four basaltic rocks, four andesitic rocks and three felsic rocks. The results are listed in Table 3. The three groups of rocks have different $\mathrm{Nd}$ isotopic compositions. The basaltic samples have relatively constant ${ }^{147} \mathrm{Sm} /{ }^{144} \mathrm{Nd}(0.1013-0.1052)$ and ${ }^{143} \mathrm{Nd} /{ }^{144} \mathrm{Nd}(0.51229-0.51244)$ ratios, corresponding to initial $\varepsilon \mathrm{Nd}(\mathrm{T})$ values of 3.1 to 6.0 and singlestage $\mathrm{Nd}$ model ages $\left(\mathrm{T}_{\mathrm{DM}}\right)$ of $1.0-1.2 \mathrm{Ga}$. The andesitic rocks have significantly lower and uniform ${ }^{147} \mathrm{Sm} /{ }^{144} \mathrm{Nd}(0.0868-0.0991)$ and ${ }^{143} \mathrm{Nd} /{ }^{144} \mathrm{Nd}$ $(0.51152-0.51158)$ ratios. Thus, they have significantly lower $\varepsilon \mathrm{Nd}(\mathrm{T})$ values of -9.3 to -11.1 and older two-stage $\mathrm{Nd}$ model ages $\left(\mathrm{T}_{2 \mathrm{DM}}\right)$ of $2.3-2.4 \mathrm{Ga}$, suggesting a Palaeoproterozoic/Neoarchaean source for these rocks. The rhyolitic rocks show constant Sm$\mathrm{Nd}$ isotopic compositions, with ${ }^{147} \mathrm{Sm} /{ }^{144} \mathrm{Nd}=0.1103$ $0.1268,{ }^{143} \mathrm{Nd} /{ }^{144} \mathrm{Nd}=0.51201-0.51202$, corresponding to $\varepsilon \mathrm{Nd}(\mathrm{T})$ values of -2.9 to -4.7 and $\mathrm{T}_{2 \mathrm{DM}}$ ages of 1.7-1.9 Ga, in between those of the associated basaltic and andesitic rocks. The $\mathrm{Sm}-\mathrm{Nd}$ isotopic compositions of the rhyolites are also comparable with those of the regional c. $820 \mathrm{Ma}$ peraluminous granitoids (Li et al. 2003a; Wu et al. 2006). 

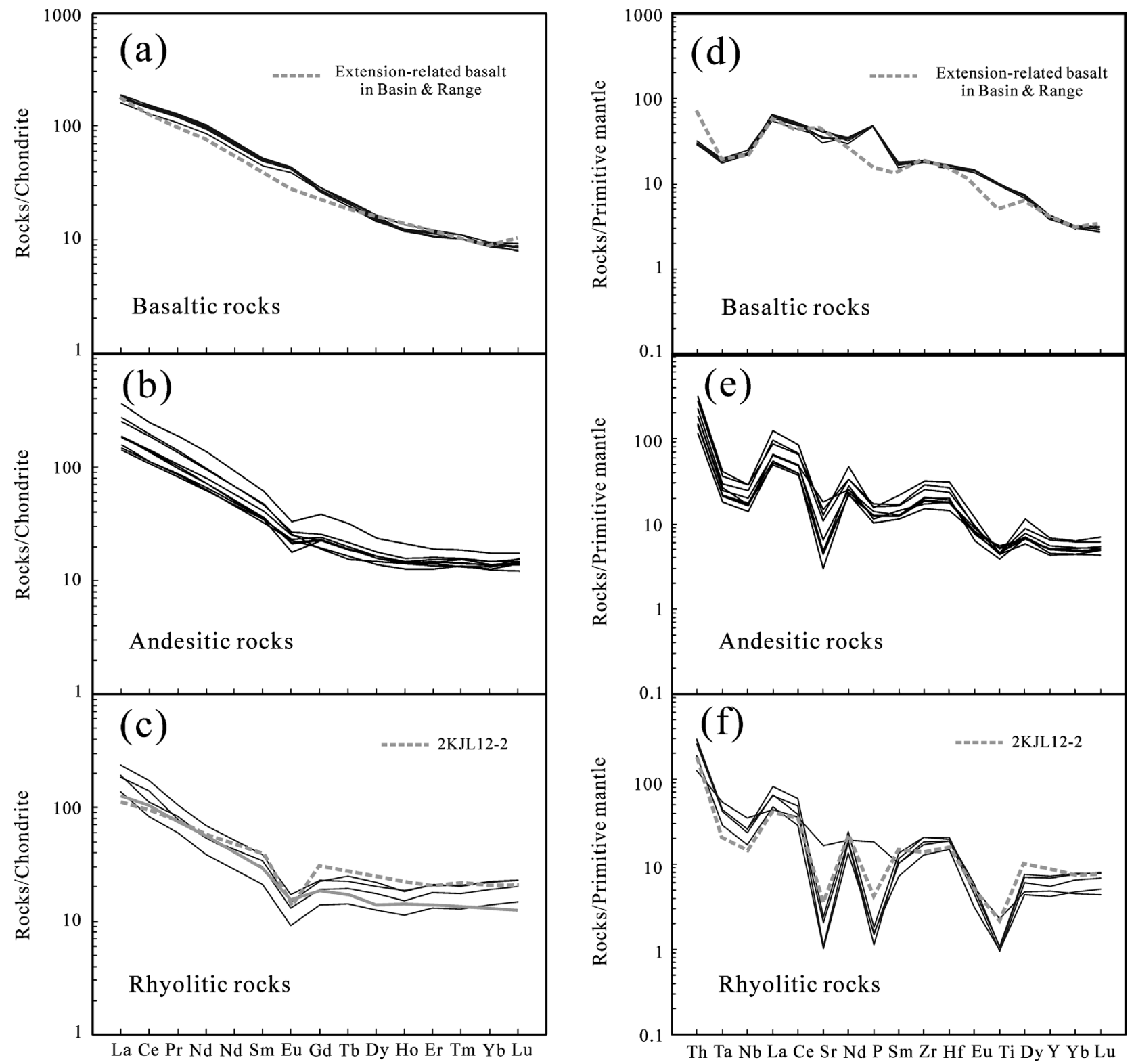

Figure 4. Chondrite-normalized REE diagrams $(\mathrm{a}-\mathrm{c})$ and primitive mantle-normalized trace elements diagrams $(\mathrm{d}-\mathrm{f})$. The basalts show REE and trace elements patterns similar to that of the Cenozoic extension-related basalts in the Basin \& Range Province, and the rhyolites similar to that of the $c$. $825 \mathrm{Ma}$ peraluminous granites. Data from Cenozoic basalts in the Basin \& Range are after Hawkesworth et al. (1995). Sample 2KJL12-2 is a c. 820 Ma peraluminous granite in northern Jiangxi (after Li et al. 2003a). Normalization values are after Sun \& McDonough (1989).

\section{Petrogenesis}

\section{5.a. Basaltic rocks}

The Guangfeng alkaline basaltic rocks are characterized by high HSFE contents such as $\mathrm{Nb}=16$ $18 \mathrm{ppm}, \mathrm{Zr}=197-207 \mathrm{ppm}$ and $\mathrm{TiO}_{2}=2.07-2.16 \%$. On the tectonic discrimination diagrams of $\mathrm{Ti}-\mathrm{Zr}-\mathrm{Y}$ (Pearce \& Cann, 1973) and Ti-Sm-V (Vermeesch, 2006), they plot exclusively into the OIB field, consistent with the same-aged Suxiong and Mamianshan alkaline basalts from the western Yangtze and northern Cathaysia blocks, respectively (Fig. 5a, b). In addition, the Guangfeng basalts are high in $\mathrm{Zr} / \mathrm{Y}$ (11-12), exhibiting a broad geochemical similarity to the Cenozoic extension-related basalts in the Basin and Range Province (e.g. Hawkesworth et al. 1995).

The Guangfeng basalts show clear $\mathrm{Nb}-\mathrm{Ta}$ negative anomalies $(\mathrm{Nb} / \mathrm{La}=0.37-0.41)$ (Fig. 4d), an oftenquoted 'diagnostic' feature of arc basalts, but their geochemical characteristics are significantly different from those of arc basalts (Fig. 6). Depletion in $\mathrm{Nb}$ and $\mathrm{Ta}$ relative to $\mathrm{La}$ and $\mathrm{Th}$ in the intraplate basalts could be attributed to different processes including: (1) fractional crystallization of Ti-bearing minerals such as titanomagnetite, (2) contamination by crustal material during ascent of magmas, and (3) inheritance from 
Table 3. Nd isotopic results for Guangfeng volcanic rocks

\begin{tabular}{lcccccccc}
\hline & $\mathrm{Sm}(\mathrm{ppm})$ & $\mathrm{Nd}(\mathrm{ppm})$ & ${ }^{147} \mathrm{Sm} /{ }^{144} \mathrm{Nd}$ & ${ }^{143} \mathrm{Nd} /{ }^{144} \mathrm{Nd}$ & $\pm 2 \sigma_{\mathrm{m}}$ & $\varepsilon \mathrm{Nd}(\mathrm{T})$ & $\mathrm{T}_{\mathrm{DM}}(\mathrm{Ga})$ & $\mathrm{T}_{2 \mathrm{DM}}(\mathrm{Ga})$ \\
\hline Basalt & & & & & & & & \\
03SC05-4 & 7.75 & 44.57 & 0.105 & 0.512366 & 0.000008 & 4.38 & 1.10 & \\
03SC05-7 & 7.82 & 46.65 & 0.101 & 0.512328 & 0.000009 & 4.04 & 1.12 & \\
03SC05-8 & 7.34 & 42.93 & 0.103 & 0.512292 & 0.000008 & 3.13 & 1.19 & \\
03SC05-9 & 6.72 & 39.57 & 0.103 & 0.512287 & 0.000008 & 6.00 & 0.98 & \\
Andesite & & & & & & & & \\
03SC05-1 & 7.33 & 45.58 & 0.097 & 0.511528 & 0.000007 & -11.14 & 2.12 & 2.39 \\
03SC05-3 & 7.39 & 45.08 & 0.099 & 0.511548 & 0.000007 & -10.96 & 2.13 & 2.38 \\
02SC09-4 & 5.41 & 34.05 & 0.096 & 0.511577 & 0.000009 & -10.05 & 2.03 & 2.31 \\
02SC10-1 & 9.57 & 63.95 & 0.090 & 0.511584 & 0.000007 & -9.34 & 1.93 & 2.25 \\
Rhyolite & & & & & & & & \\
03SC04-2 & 3.42 & 18.69 & 0.110 & 0.512024 & 0.000007 & -2.86 & 1.66 & 1.72 \\
03SC04-3 & 5.32 & 25.36 & 0.127 & 0.512017 & 0.000009 & -4.72 & 1.98 & 1.87 \\
03SC04-4 & 4.68 & 25.66 & 0.110 & 0.512009 & 0.000007 & -3.14 & 1.68 & 1.75 \\
\hline
\end{tabular}

$\mathrm{T}=827 \mathrm{Ma}$, formation age of Guangfeng volcanic rocks. Single- and two-stage Nd model age, $\mathrm{T}_{\mathrm{DM}}$ and $\mathrm{T}_{2 \mathrm{DM}}$ are calculated using formulas and parameters given by Li et al. (2003a).

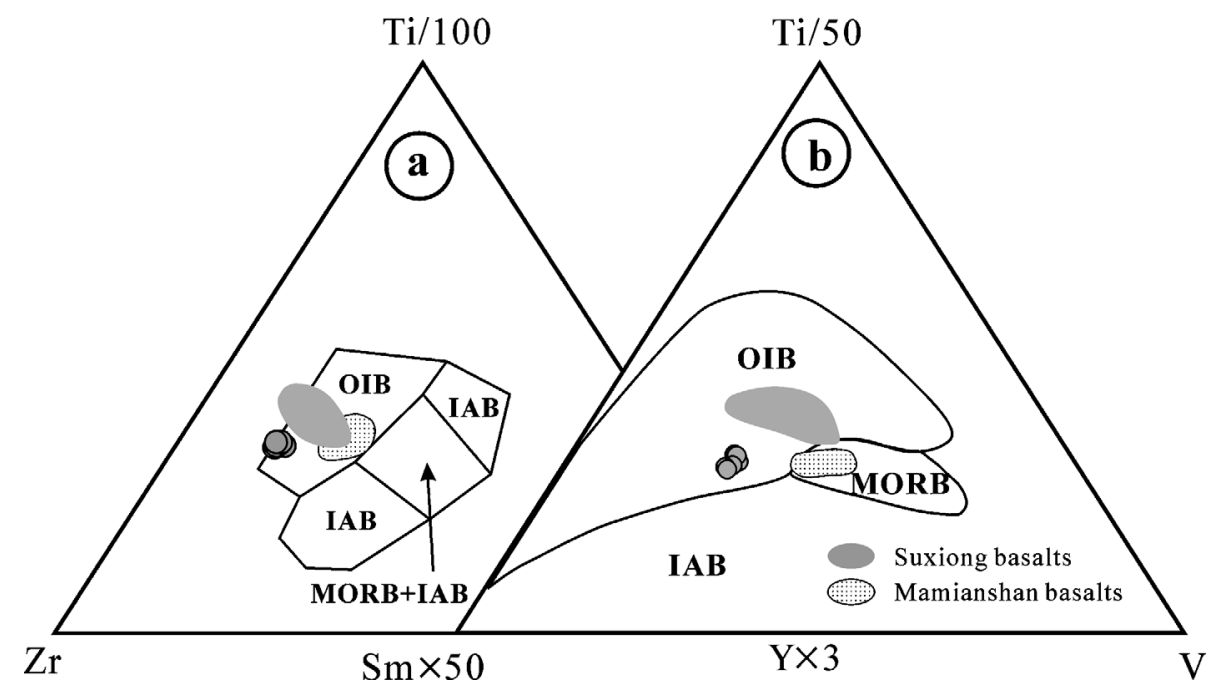

Figure 5. Tectonic discrimination diagram of (a) Ti-Zr-Y (Pearce \& Cann, 1973) and (b) Ti-Sm-V (Vermeesch, 2006) for the Guangfeng basalts. The coveal Suxiong and Mamianshan basalts are shown for comparison (data after Li et al. $2002 a$ and $\mathrm{Li}, \mathrm{Li} \& \mathrm{Li}$, 2005). Symbols are as in Figure 3.

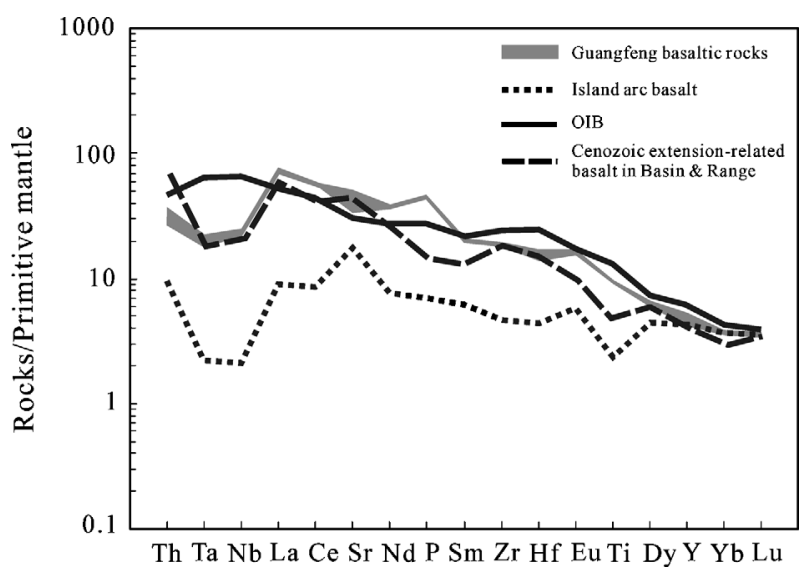

Figure 6. Comparison of incompatible trace element spider diagrams between the Guangfeng basalts and the average island-arc basalt (McCulloch \& Gamble, 1991), OIB (Sun \& McDonough, 1989) and Cenozoic basalt in the Basin and Range Province (Hawkesworth et al. 1995). their mantle source which had been previously metasomatized by subduction-related fluids and/or melts. The Guangfeng basalts are characteristically high in $\mathrm{TiO}_{2}(>2.0 \%)$ without visible $\mathrm{Ti}$ negative anomaly in the primitive mantle-normalized spidergrams (Fig. 4d), precluding significant fractional crystallization of titanomagnetite. It is noted that these basalts have lower $\mathrm{Nb} / \mathrm{La}$ ratios $(0.37-0.41)$ than those of crustal sources $(\mathrm{Nb} / \mathrm{La}=0.47-0.83$ : Rudnick \& Fountain, 1995). Considering their high-positive $\varepsilon \mathrm{Nd}(\mathrm{T})$ values, crustal contamination should have played very minor, if any, roles in the genesis of these basalts. Thus, their depletion in $\mathrm{Nb}-\mathrm{Ta}$ relative to $\mathrm{La}$ and $\mathrm{Th}$ is most likely inherited from the mantle source that had been previously metasomatized by subduction-related fluids/melts. The Guangfeng basalts have super-chondritic $\mathrm{Nb} / \mathrm{Ta}$ ratios of 20.5 to 22.1, inconsistent with same-aged Suxiong and Mamianshan basalts which have $\mathrm{Nb} / \mathrm{Ta}$ ratios 


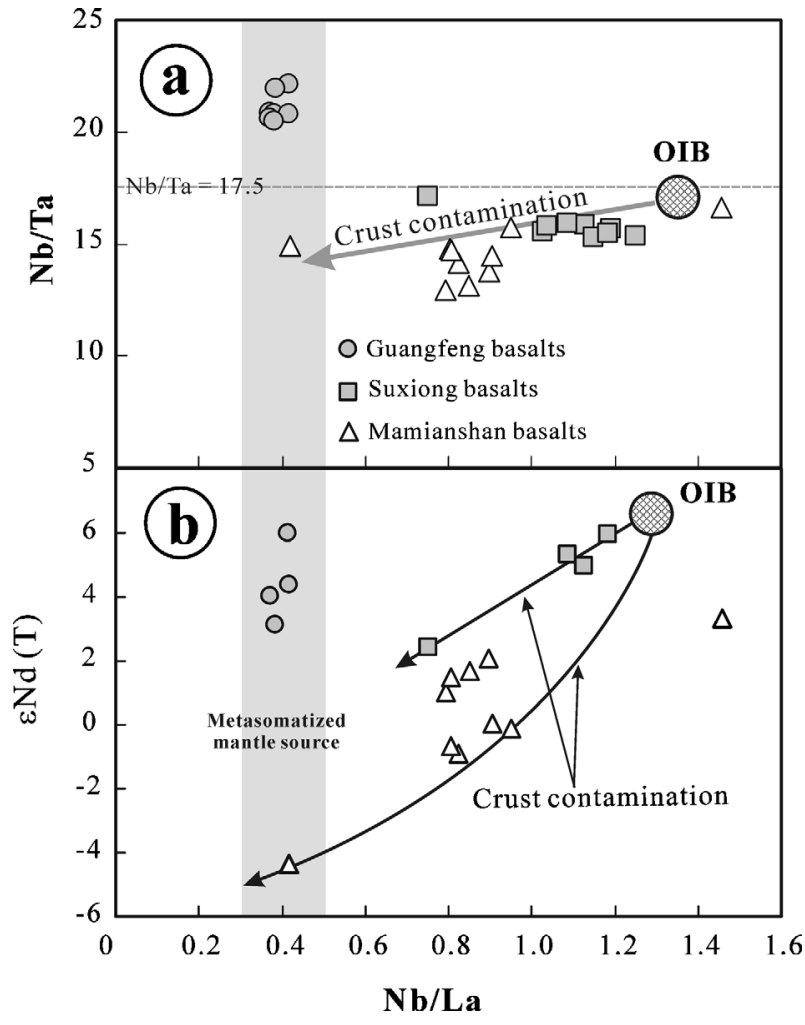

Figure 7. Plots of (a) $\mathrm{Nb} / \mathrm{La} \mathrm{v} . \mathrm{Nb} / \mathrm{Ta}$ and (b) $\mathrm{Nb} / \mathrm{La} \mathrm{v} \cdot \varepsilon \mathrm{Nd}(\mathrm{T}$ ) show that the Guangfeng basalts have super-chondritic $\mathrm{Nb} / \mathrm{Ta}$ and low $\mathrm{Nb} / \mathrm{La}$ ratios, suggesting derivation from siliceous melting of a metasomatized mantle source, whereas the sameaged Suxiong and Mamianshan basalts in the western Yangtze and northern Cathaysia blocks, respectively, have sub-chondritic $\mathrm{Nb} / \mathrm{Ta}$ ratios $(<17.5)$, relative high $\mathrm{Nb} / \mathrm{La}$ ratios and obvious crustal contamination trends, suggesting that they were derived mainly from OIB-like mantle sources with contamination of crustal materials. Data of the Suxiong and Mamianshan basalts are from from $\mathrm{Li}$ et al. (2002a) and $\mathrm{Li}, \mathrm{Li} \& \mathrm{Li}$ (2005), respectively.

exclusively below 17.5 (Fig. 7a). Because the $\mathrm{Nb} / \mathrm{Ta}$ ratios of lower to upper crust are in the range of 8.3 to 11.3 (Rudnick \& Fountain, 1995), the super-chondritic $\mathrm{Nb} / \mathrm{Ta}$ ratios of the Guangfeng basalts should have been inherited from the mantle source, rather than caused by the contamination of crustal material. Numerous experimental and geochemical studies indicate that siliceous melts derived from subducted oceanic slab have super-chondritic $\mathrm{Nb} / \mathrm{Ta}$ ratios due to residual rutile in the source which could significantly fractionate $\mathrm{Nb}$ from $\mathrm{Ta}$, whereas the opposite effect was observed for rutile in slab-derived fluids (Green \& Pearson, 1987; Brenan et al. 1994; Keppler, 1996; Stolz et al. 1996; Münker, 1998; Münker et al. 2004; Xiong, Adam \& Green, 2005; Xiong et al. 2006; Xiong, 2006). Therefore, the Guangfeng basaltic rocks were most likely generated by partial melting of a subcontinental lithospheric mantle source that had been metasomatized by slab-derived melts. Their $\mathrm{T}_{\mathrm{DM}}$ ages of $1.0-1.2 \mathrm{Ga}$ suggest that the mantle

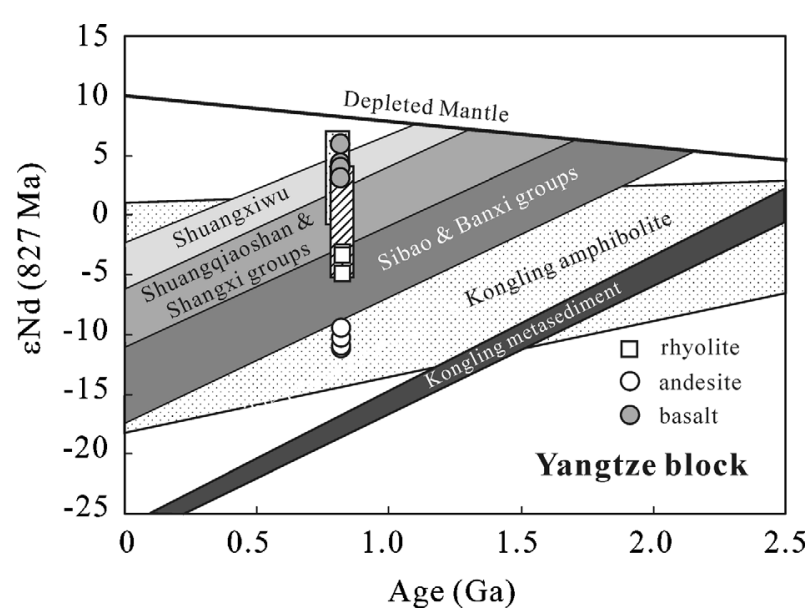

Figure 8. Nd isotopic evolution plot of the Guangfeng volcanic rocks. Nd isotopic evolution trends for the Yangtze Block are after Chen \& Jahn, (1998) and Gao et al. (1999). Small vertical rectangles with dots and stripes indicate the Suxiong and Mamianshan basalts, respectively. $\mathrm{Nd}$ isotopic data from the Suxiong and Mamianshan basalts are from Li et al. (2002a) and $\mathrm{Li}, \mathrm{Li} \& \mathrm{Li}(2005)$.

metasomatism might have taken place shortly before their formation, possibly during the $c$. $1.1-0.9 \mathrm{Ga}$ Sibao orogeny (e.g. Li et al. 2002b, 2007c; Li \& Li, 2003; Ye et al. 2007).

\section{5.b. Andesitic rocks}

Three main viewpoints have been proposed to interpret the origin of andesitic rocks: (1) fractionated crystallization of basaltic rocks derived from mantle peridotite; (2) dehydration partial melting of metabasalts (amphibolites) or metasedimentary rocks in the lower or middle crust by underplating and/or intrusions of hot, mantle-derived magma; and (3) mixing of mantle-derived basaltic magmas with crust-derived felsic melts.

The Guangfeng andesitic rocks have significantly lower $\varepsilon \mathrm{Nd}(\mathrm{T})$ values (between -9.3 and -11.1 ) than the associated basaltic rocks which have high positive $\varepsilon \mathrm{Nd}(\mathrm{T})$ values of 3.1 to 6.0 , indicating that the andesitic rocks were unlikely to have originated by simple fractional crystallization of the basaltic parental magmas. The andesites are characterized by a wide range of $\mathrm{SiO}_{2}$ contents $(57.62-65.60 \%)$ and early Palaeoproterozoic $\mathrm{T}_{2 \mathrm{DM}}$ ages of 2.3-2.4 Ga, suggesting significant involvement of ancient crustal components. Furthermore, their $\mathrm{T}_{2 \mathrm{DM}}$ values are obviously older than most pre-900 Ma metasedimentary rocks in the southeastern margin of the Yangtze Block (e.g. Chen \& Jahn, 1998; Li \& McCulloch, 1996), indicating that there likely exist unexposed ancient crustal rocks (Fig. 8). Such Palaeoproterozoic- to Archaean-aged basement rocks are exposed in the Kongling area of the northern Yangtze Block only (Gao et al. 1999; Qiu et al. 2000; Zhang et al. 2006a,b), but could be widespread 
beneath the whole Yangtze Block as well (e.g. Zheng et al. 2006; Greentree et al. 2006). Although the Kongling amphibolites have $\varepsilon \mathrm{Nd}(\mathrm{T})$ values between 1.5 and -11.9 at $825 \mathrm{Ma}$, broadly consistent with the $\varepsilon \mathrm{Nd}(\mathrm{T})$ values of Guangfeng andesites $(-9.3$ to -11.1), equilibrium partial melting calculations on the basis of the trace elements $(\mathrm{Nb}$ and $\mathrm{Zr})$ indicate that it would require about $60-70 \%$ melting of the Kongling amphibolites to match the trace element features of the Guangfeng andesites (assuming the residual mineral assemblage is $\mathrm{Pl}: \mathrm{Cpx}: \mathrm{Opx}: \mathrm{Mt} \approx 55: 30: 5: 10$ and $\mathrm{D}_{\mathrm{Nb}}=0.23, \mathrm{D}_{\mathrm{Zr}}=0.11$ : Beard \& Lofgren, 1991; Rollinson, 1993). Such large degrees of melting are inconceivable and inconsistent with the experimental results $\left(\mathrm{SiO}_{2}\right.$ generally $>60 \%$ and melting percentage $<40 \%$ at water-unsaturated dehydration condition: Beard \& Lofgren, 1991). Therefore, partial melting of the Archaean amphibolites alone is unlikely to have produced the Guangfeng andesite.

It is noteworthy that the $\varepsilon \mathrm{Nd}(\mathrm{T})$ values of the Guangfeng andesitic rocks are even lower than those of the associated felsic volcanic rocks $(\varepsilon \mathrm{Nd}(\mathrm{T})=-2.9$ to -4.7 ), indicating that these andesitic rocks could not have been formed by mixing of mantle-derived basaltic magmas and associated felsic melts. However, generation by mixing of basaltic magmas with felsic melts derived from unexposed ancient middle-lower crustal rocks, such as the Kongling metasedimentary rocks (e.g. Gao et al. 1999), is possible. Twocomponent mixing calculations suggest that the Guangfeng andesites could have been formed by mixing of the associated basalts with about $30-40 \%$ of the Kongling metasediments (Fig. 9a, b). It is noted that the andesitic rocks have a wide range of $\mathrm{SiO}_{2}$ and their $\mathrm{Th} / \mathrm{Ta}$ ratios increase slightly with increasing $\mathrm{Zr}$ content (Fig. 9c), suggesting strong fractional crystallization. Niobium, Th and REE are positively correlated with $\mathrm{Zr}$ (Fig. 3), suggesting that clinopyroxene and plagioclase are predominant minerals involved in fractional crystallization, because the partition coefficients of these elements in clinopyroxene and plagioclase are $<1$ for the andesitic melts, whereas they are $>1$ in amphibole (Rollinson, 1993).

\section{5.c. Felsic rocks}

The Guangfeng rhyolites are peraluminous with $\mathrm{A} / \mathrm{CNK}$ values of $>1.6$. They have relatively homogeneous negative $\varepsilon \mathrm{Nd}(\mathrm{T})$ values of -2.9 to -4.7 and late Palaeoproterozoic $\mathrm{T}_{2 \mathrm{DM}}$ ages of 1.7-1.9 Ga. Overall, their geochemical features are similar to those of the c. $820 \mathrm{Ma}$ peraluminous granitoids in the southern Anhui and northeastern Jiangxi provinces (Li et al. 2003a; Wu et al. 2006), suggesting a predominant contribution from late Palaeoproterozoic to Mesoproterozoic crustal source (Fig. 8). These rocks are high in $\mathrm{Zr}$ (148-218 ppm), corresponding to the zircon saturation temperatures $\left(\mathrm{T}_{\mathrm{Zr}}\right)$ of between 817 and
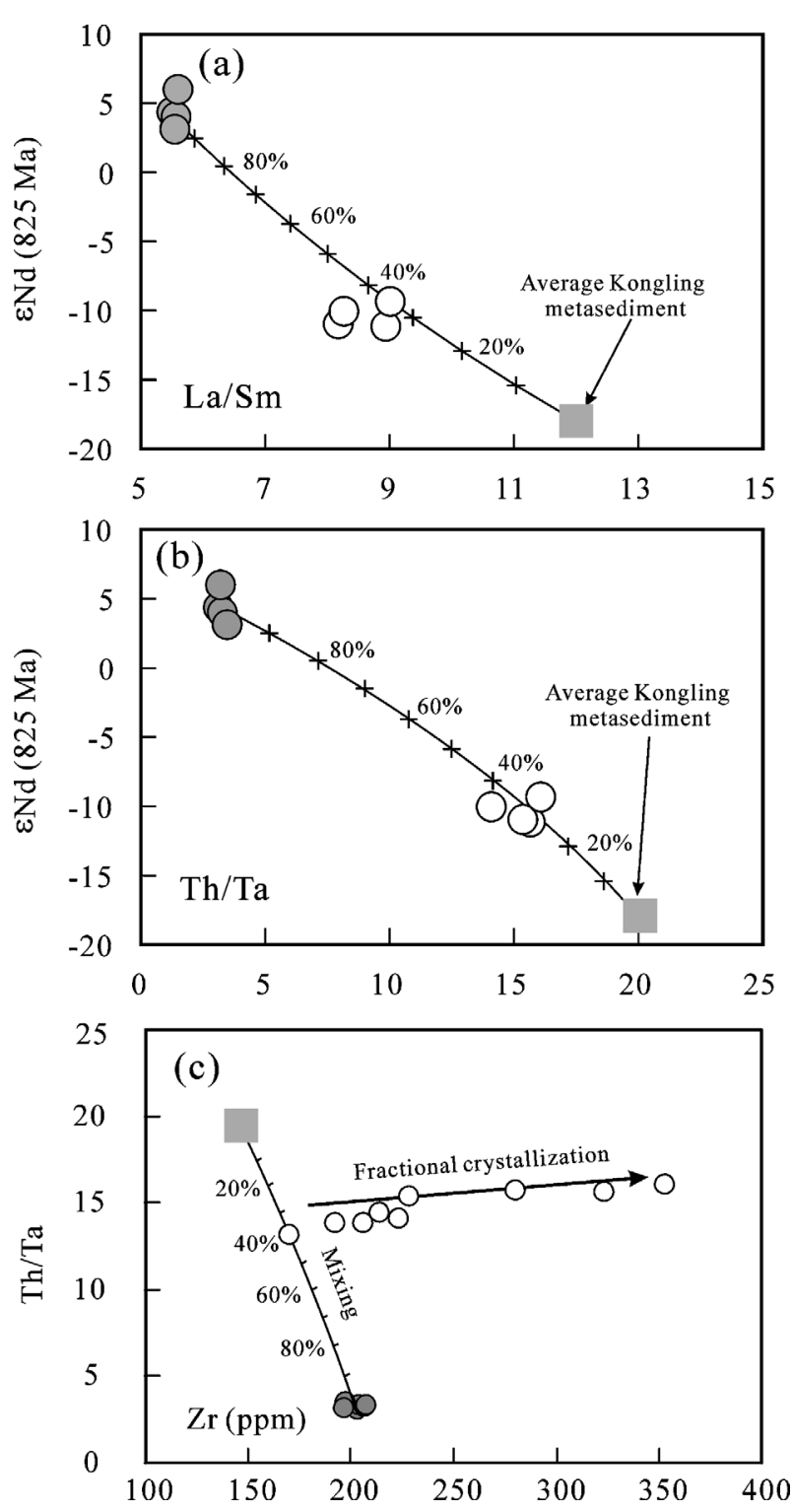

Figure 9. Plots of (a) $\varepsilon \mathrm{Nd}(\mathrm{T})$ v. $\mathrm{La} / \mathrm{Sm}$, (b) $\varepsilon \mathrm{Nd}(\mathrm{T}) \mathrm{v}$. $\mathrm{Th} / \mathrm{Ta}$ and (c) $\mathrm{Th} / \mathrm{Ta}$ v. Zr, showing two-component mixing modal calculation for the generation of the Guangfeng andesites. The andesites could have been formed by mixing of evolved basalt magmas with about $30-40 \%$ felsic melts derived from the Archaean Kongling metasediments (Gao et al. 1999), followed by fractional crystallization. Symbols are as in Figure 3.

$862^{\circ} \mathrm{C}$ (Table 2). In combination with their relatively low $\mathrm{Al}_{2} \mathrm{O}_{3} / \mathrm{TiO}_{2}$ ratios of $<70$, the rhyolite rocks were likely generated by high temperature partial melting (Sylvester, 1998) of metasedimentary rocks caused by hot mantle upwelling, or basaltic magma underplating and/or intrusions during lithospheric thinning in a continental rift environment.

\section{Tectonic significance}

SHRIMP U-Pb zircon dating results indicate that the Guangfeng volcanic rocks were formed at c. $825 \mathrm{Ma}$. They are coeval with the widespread Neoproterozoic 
syn-rift basaltic and felsic volcanic rocks throughout South China, including the $817 \pm 5$ Ma Tiechuanshan bimodal basalte-dacite/rhyolite in the northwestern Yangtze Block (Ling et al. 2003), the $800-810 \mathrm{Ma}$ Suxiong bimodal basalt-dacite/rhyolite along the western margin of the Yangtze Block (Li et al. 2002a), the $819 \pm 11 \mathrm{Ma}$ Yingyangguan spilite-keratophyre (Zhou et al. 2002a), the $814 \pm 12 \mathrm{Ma}$ Changshuipu dacitic agglomerate (Wang et al. 2003) in southern Yangtze Block, and the $818 \pm 9 \mathrm{Ma}$ Mamianshan bimodal volcanic rocks in northern Cathaysia $(\mathrm{Li}$, Li \& Li, 2005). This giant magmatic event was commonly considered to be a result of anorogenic magmatism caused by the c. 825 Ma South China mantle plume that triggered the initial rifting of the supercontinent Rodinia (Li, 1999; Li et al. 2002a, 2003a; Wang et al. 2007). Moreover, compared with similar-aged anorogenic magmatism recorded in numerous other Rodinian continents, Li et al. $(2003 b)$ proposed that a mantle superplume caused the global-scale contemporaneous magmatism at c. 830 $740 \mathrm{Ma}$. In contrast, some other workers speculated that active continental margins existed around the Yangtze Block during middle Neoproterozoic times, and the 860-750 Ma igneous rocks are products related to subduction of oceanic plate and collision between the Yangtze and Cathaysia blocks (e.g. Zhou et al. 2002b,c, 2006a,b; Wang et al. 2004, 2006; Munteanu \& Yao, 2007). This arc model is mainly based on some 'arclike' geochemical signatures such as depletion of $\mathrm{Nb}$ and $\mathrm{Ta}$ relative to $\mathrm{La}$ and $\mathrm{Th}$, but inconsistent with many aspects of geological observations (e.g. Li et al. $2007 a, b)$.

We emphasize that $\mathrm{Nb}-\mathrm{Ta}$ depletion in some middle Neoproterozoic basalts in South China is mainly attributed to either derivation from the metasomatized mantle sources or contamination by crustal components. Figure $7 \mathrm{a}$ and $\mathrm{b}$ are plots of $\mathrm{Nb} / \mathrm{Ta}$ and $\varepsilon \mathrm{Nd}(\mathrm{T})$ v. $\mathrm{Nb} / \mathrm{La}$ for three similar-aged (c. 820 $800 \mathrm{Ma}$ ) alkaline basalts from Suxiong of the western Yangzte Block, Mamianshan of northern Cathaysia and Guangfeng of this study (also see Fig. 1a). Both the Suxiong and Mamianshan basalts display obvious trends between the OIB-type mantle-derived magmas and the crustal components, whereas the Guangfeng basalts are derived dominantly from a metasomatized mantle source. It has been argued that the Suxiong and Mamianshan alkaline basalts are typical products of intracontinental rifting magmatism. Despite showing varying degrees of depletion in $\mathrm{Nb}$ and $\mathrm{Ta}$ relative to $\mathrm{La}$ and $\mathrm{Th}$, the Guangfeng basalts also show a broad geochemical similarity to typical intraplate basalts, similar to other middle Neoproterozoic basalts and dykes in South China that also show $\mathrm{Nb}$ and $\mathrm{Ta}$ depletions (e.g. Li et al. 2003a; Ling et al. 2003; Lin, Li \& Li 2007; Zhou et al. 2007). Intraplate magmatic rocks with $\mathrm{Nb}$ and $\mathrm{Ta}$ depletion are also seen in other continents (e.g. Harry \& Leeman, 1995;
Hawkesworth et al. 1995; Morris, Larson \& Hooper, 2000; Romer, Forster \& Breitkreuz, 2001), which are mostly associated with former plate convergence zones. Therefore, depletion of $\mathrm{Nb}$ and $\mathrm{Ta}$ in basaltic rocks cannot be simplistically used as a definitive indicator for active subduction tectonic settings.

\section{Conclusions}

SHRIMP U-Pb zircon analysis suggests that the Guangfeng volcanic rocks were erupted at $827 \pm 14 \mathrm{Ma}$, coeval with the early phase of middle Neoproterzoic rift-related igneous rocks in South China and other Rodinia continents. They were generated by partial melting of a slab melt-metasomatized subcontinental lithospheric mantle source in an intracontinental rifting setting. The associated andesites were likely generated by mixing of fractionated basaltic melts with felsic melts derived from the Archaean metasedimentary rocks, followed by fractional crystallization of clinopyroxene and plagioclase. The rhyolites were derived from Mesoproterozoic sedimentary sources at relatively shallow levels. We thus concluded that the Guangfeng volcanic suite is a magmatic response of different levels of continental lithosphere (including lithospheric mantle and the lower-middle to upper crustal levels) to the middle Neoproterozoic intracontinental rifting possibly caused by a mantle plume. These syn-rifting volcanic rocks inherited some 'arc-like' geochemical signatures from their sources, consistent with the fact that the Guangfeng rift basin was developed within a former mobile zone.

Acknowledgements. We appreciate the assistance of Y. Liu, $\mathrm{X}$. L. Tu, and X. R. Liang in geochemical and $\mathrm{Nd}$ isotopic analyses, and B. Song and H. Tao in SHRIMP U-Pb zircon analyses, J. Wang and C.M. Bao are thanked for help with field work; X.C. Wang is thanked for help with modal calculation. Review comments of Drs M. Sun, Y. F. Zheng and X. L. Wang have been helpful. We particularly thank the editor Dr David Pyle for his detailed and constructive review on an early version of this paper. This work was supported by the Chinese Academy of Sciences (KZCX3-SW-141, 2003-1-2) and NSFC (grants 40421303, 40372040 and 40573016) and ARC Discovery Project grants (DP0450020 and DP0770228). This is TIGeR (The Institute of Geoscience Research) publication no. 69.

\section{References}

BeARD, J. S. \& LofGRen, G. E. 1991. Dehydration melting and water saturated melting of basaltic and andesitic greenstones and amphibolites at 1,3 and $6.9 \mathrm{~kb}$. Journal of Petrology 32, 365-401.

Black, L. P., Kamo, S. L., Allen, C. M., Aleinikoff, J. N., DAVIS, D. W., Korsch, R. J. \& FoudOulis, C. 2003. TEMORA 1: a new zircon standard for Phanerozoic U-Pb geochronology. Chemical Geology 200, 155-70.

Brenan, J. M., Shaw, H. F., Phinney, D. L. \& Ryerson, F. J. 1994. Rutile-aqueous fluid partitioning of $\mathrm{Nb}$, 
Ta, Hf, Zr, U and Th: implications for high field strength element depletions in islandarc basalts. Earth and Planetary Science Letters 128, 327-39.

CHEN, J. F. \& JAHN, B. M. 1998. Crustal evolution of southeastern China: $\mathrm{Nd}$ and $\mathrm{Sr}$ isotopic evidence. Tectonophysics 284, 101-33.

CUMMING, G. L. \& RichaRDS, J. R. 1975. Ore lead isotope ratios in a continuously changing earth. Earth and Planetary Science Letters 28, 155-71.

GAO, S., LING, W. L., QIU, Y. M., ZhOU, L., HARTMANN, G. \& SiMON, K. 1999. Contrasting geochemical and Sm$\mathrm{Nd}$ isotopic compositions of Archean metasediments from the Kongling high-grade terrain of the Yangtze Craton: Evidence for cratonic evolution and redistribution of REE during crustal anatexia. Geochimica et Cosmochimica Acta 63, 2071-88.

GibSON, S. A., KIRKPATRICK, R. J., EMMERMAN, R., SCHMINCKE, P.-H., PRITCHARD, G., OKAY, P. J., THORPE, R. S. \& MARriner, G. F. 1982. The trace element composition of the lavas and dykes from a $3 \mathrm{~km}$ vertical section through a lava pile of Eastern Iceland. Journal of Geophysical Research 87, 6532-46.

GreEN, T. H. \& PEARson, N. J. 1987. An experimental study of $\mathrm{Nb}$ and $\mathrm{Ta}$ partitioning between Ti-rich minerals and silicate liquids at high pressure and temperature. Geochimica et Cosmochimica Acta 51, 55-62.

Greentree, M. R., LI, Z. X., Li, X. H. \& WU, H. 2006. Late Mesoproterozoic to earliest Neoproterozoic basin record of the Sibao orogenesis in western South China and relationship to the assembly of Rodinia. Precambrian Research 151, 79-100.

GUAN, T. \& YU, D. 1993. Characteristics and geological significance on the strata section of earlier late Proterozoic era in Guangfeng area of Jiangxi. Journal of East China Geological Institute 16(4), 385-94 (in Chinese with English abstract).

HARRY, D. L. \& LEEMAN, W. P. 1995. Partial melting of melt metasomatized subcontinental mantle and magma source potential of the lower lithosphere. Journal of Geophysical Research 100, 10255-69.

HaWkesworth, C., Turner, S., Gallagher, K., Hunter, A., Bradshaw, T. \& Rogers, N. 1995. Calc-alkaline magmatism, lithospheric thinning and extension in the Basin and Range. Journal of Geophysical Research $\mathbf{1 0 0}$, 10271-86.

KEPPLER, H. 1996. Constraints from partitioning experiments on the composition of subduction-zone fluids. Nature 380, 237-40.

LI, W. X. \& LI, X. H. 2003. Adakitic granites within the NE Jiangxi ophiolites, South China: geochemical and $\mathrm{Nd}$ isotopic evidence. Precambrian Research 122, 29-44.

LI, W. X., LI, X. H. \& LI, Z. X. 2005. Neoproterozoic bimodal magmatism in the Cathaysia Block of South China and its tectonic significance. Precambrian Research 136, $51-66$.

LI, X. H. 1997. Timing of the Cathaysia block formation: constraints from SHRIMP U-Pb zircon geochronology. Episodes 20, 188-92.

LI, X. H. 1999. U-Pb zircon ages of granites from the southern margin of the Yangtze block: Timing of the Neoproterozoic Jinning orogeny in SE China and implications for Rodinia. Precambrian Research 97, 43-57.

LI, X. H., Li, Z. X., Ge, W., Zhou, H., LI, W. X., LiU, Y. \& WINGATE, M. T. D. $2003 a$. Neoproterozoic granitoids in South China: crustal melting above a mantle plume at 825 Ma? Precambrian Research 122, 45-83.
LI, X. H., Li, Z. X., Sinclair, J. A., LI, W. X. \& CARTER, G. 2006. Revisiting the "Yanbian Terrane": Implications for Neoproterozoic tectonic evolution of the western Yangtze Block, South China. Precambrian Research 151, 14-30.

Li, X. H., Li, Z. X., Sinclair, J. A., Li, W. X. \& Carter, G. 2007a. Reply to the comment by Zhou et al. on: "Revisiting the 'Yanbian Terrane': Implications for Neoproterozoic tectonic evolution of the western Yangtze Block, South China”. Precambrian Research 155, 318-23.

Li, X. H., LI, Z. X., Sinclair, J. A., Li, W. X. \& CARTER, G. 2007b. Understanding dual geochemical characters in a geological context for the Gaojiacun intrusion: Response to Munteanu and Yao's discussion. Precambrian Research 155, 328-32.

Li, X. H., Li, Z. X., Zhou, H., LiU, Y. \& KinNY, P. D. $2002 a$. U-Pb zircon geochronology, geochemistry and $\mathrm{Nd}$ isotopic study of Neoproterozoic bimodal volcanic rocks in the Kangdian Rift of South China: implications for the initial rifting of Rodinia. Precambrian Research 113, 135-54.

LI, X. H., LiU, D. Y., Sun, M., LI, W. X., LianG, X. R. \& LIU, Y. 2004. Precise Sm-Nd and U-Pb isotopic dating of the super-giant Shizhuyuan polymetallic deposit and its host granite, Southeast China. Geological Magazine 141, 225-31.

LI, X. H. \& MCCULLOCH, M. T. 1996. Secular variation in the $\mathrm{Nd}$ isotopic composition of Neoproterozoic sediments from the southern margin of the Yangtze Block: evidence for a Proterozoic continental collision in southeast China. Precambrian Research 76, 67-76.

LI, X. H., QI, C. S., LIU, Y., LianG, X. R., TU, X. L., XIE, L. W. \& YANG, Y. H. 2005. Petrogenesis of the Neoproterozoic bimodal volcanic rocks along the western margin of the Yangtze Block: new constraints from Hf isotopes and Fe/Mn ratios. Chinese Science Bulletin 50, 2481-6.

Li, X. H., Sun, M., WeI, G. J., LiU, Y., LeE, C. Y. \& MALPAS, J. G. 2000. Geochemical and Sm-Nd isotopic study of amphibolites in the Cathaysia block, SE China: evidence for extremely depleted mantle in the Paleoproterozoic. Precambrian Research 102, 251-62.

LI, Z. X. \& LI, X. H. 2007. Formation of the $1300 \mathrm{~km}-$ wide intra-continental orogen and post-orogenic magmatic province in Mesozoic South China: A flat-slab subduction model. Geology 35, 179-82.

LI, Z. X., LI, X. H., KInNY, P. D. \& WANG, J. 1999. The breakup of Rodinia: did it start with a mantle plume beneath South China? Earth and Planetary Science Letters 173, 171-81.

LI, Z. X., LI, X. H., KinNY, P. D., WANG, J., ZhANG, S. \& ZHOU, H. 2003b. Geochronology of Neoproterozoic syn-rift magmatism in the Yangtze Craton, South China and correlations with other continents: evidence for a mantle superplume that broke up Rodinia. Precambrian Research 122, 85-109.

Li, Z. X., Li, X. H., Zhou, H. \& KinNY, P. D. $2002 b$. Grenville-aged continental collision in South China: new SHRIMP U-Pb zircon results and implications for Rodinia configuration. Geology 30, 163-6.

LI, Z. X., WANG, J., LI, X. H. \& ZHANG, S. H. 2003c. From Sibao orogenesis to Nanhua rifting: late Precambrian tectonic history of eastern South China - an overview and field guide. Beijing: Geological Publishing House, $100 \mathrm{pp}$. 
Li, Z. X., Wartho, J. A., Occhipinti, S., Zhang, C. L., LI, X. H., WANG, J. \& BAO, C. 2007c. Early history of the eastern Sibao Orogen (South China) during the assembly of Rodinia: new mica ${ }^{40} \mathrm{Ar} /{ }^{39} \mathrm{Ar}$ dating and SHRIMP U-Pb detrital zircon provenance constraints. Precambrian Research 159, 79-94.

LIN, G. C., LI, X. H. \& LI, W. X. 2007. SHRIMP U-Pb zircon age, geochemistry and $\mathrm{Nd}-\mathrm{Hf}$ isotope of Neoproterozoic mafic dyke swarms in western Sichuan: Petrogenesis and tectonic significance. Science in China Series D 50, $1-$ 16.

Ling, W., GAO, S., Zhang, B., LI, H., LiU, Y. \& ChENG, J. 2003. Neoproterozoic tectonic evolution of the northwestern Yangtze Craton, South China: implications for amalgamation and break-up of the Rodinia Supercontinent. Precambrian Research 122, 111-40.

McCulloch, M. T. \& GAMBle, J. A. 1991. Geochemical and geodynamical conatraints on subduction zone magmatism. Earth and Planetary Science Letters 102, 358-74.

Miller, C. F., McDowell, S. M. \& MAPeS, R. W. 2003. Hot and cold granites? Implications of zircon saturation temperatures and preservation of inheritance. Geology 31, 529-32.

Morris, G. A., Larson, P. B. \& Hooper, P. R. 2000. "Subduction style" magmatism in a non-subduction setting: the Colville Igneous Complex, NE Washington State, USA. Journal of Petrology 41, 43-67.

MÜNKER, C. 1998. Nb/Ta fractionation in a Cambrian arc/back arc system, New Zealand: source constraints and application of refined ICPMS techniques. Chemical Geology 144, 23-45.

MÜNKER, C., WÖRNER, G., YOGODZINSKI, G. \& CHURIKOVA, T. 2004. Behaviour of high field strength elements in subduction zones: constraints from KamchatkaAleutian arc lavas. Earth and Planetary Science Letters 224, 275-93.

MunTEAnU, M. \& YAO, Y. 2007. The Gaojiacun intrusion: Rift- or subduction-related?: Comment on "Revisiting the 'Yanbian Terrane': Implications for Neoproterozoic tectonic evolution of the western Yangtze Block, South China” by Li et al. (2006). Precambrian Research 155, 324-7.

Nelson, D. R. 1997. Compilation of SHRIMP U-Pb zircon geochronology data, 1996. Geological Survey of Western Australia Record 1997/2. Perth: Geological Survey of Western Australia, 189 pp.

PeArCE, J. A. \& CANN, J. R. 1973. Tectonic setting of basaltic volcanic rocks determined using trace element analyses. Earth and Planetary Science Letters 19, 290-300.

Qiu, Y. M., GaO, S., MCNaughton, N. J., Groves, D. I. \& LING, W. L. 2000. First evidence of $>3.2 \mathrm{Ga}$ continental crust in the Yangtze Craton of south China and its implications for Archean crustal evolution and Phanerozoic tectonics. Geology 28, 11-14.

Rollinson, H. 1993. Using geochemical data: evaluation, presentation, interpretation. Singapore: John Wiley \& Sons Inc., 352 pp.

Romer, R. L., Forster, H.-J. \& Breitkreuz, C. 2001. Intracontinental extensional magmatism with a subduction fingerprint: the late Carboniferous Halle Volcanic Complex (Germany). Contributions to Mineralogy and Petrology 141, 201-21.

Rudnick, R. L. \& Fountain, D. M. 1995. Nature and composition of the continental crust: a lower crustal perspective. Reviews of Geophysics 33, 267-309.
Stolz, A. J., Jochum, K. P., Spettel, B. \& Hofmann, A. W. 1996. Fluid- and melt-related enrichment in the subarc mantle: evidence from $\mathrm{Nb} / \mathrm{Ta}$ variations in island-arc basalt. Geology 24, 587-90.

Sun, S.-S. \& McDonough, W. F. 1989. Chemical and isotopic systematics of oceanic basalts: implications for mantle composition and processes. In Magmatism in the Ocean Basins (eds A. D. Saunders \& M. J. Norry), pp. 313-45. Geological Society of London, Special Publication no. 42.

SYlVESTER, P. J. 1998. Post-collisional strongly peraluminous granites. Lithos 45, 29-44.

TANAKA, T. and 19 co-authors. 2000. JNdi-1: a neodymium isotopic reference in consistency with LaJolla neodymium. Chemical Geology 168, 279-81.

VERMEESCH, P. 2006. Tectonic discrimination of basalts with classification trees. Geochimica et Cosmochimica Acta 70, 1839-48.

WANG, J. \& GAO, Y. 2003. Sedimentary evolution of the Guangfeng Neoproterozoic rift sub-basin, northeastern Jiangxi, South China. IGCP 440 South China Field Symposium Abstract, pp. 52-4.

WanG, J., Li, X. H., DuAn, T. Z., LiU, D. Y., SONG, B., LI, Z. \& GAO, Y. 2003. Zircon SHRIMP U-Pb dating for the Cangshuipu volcanic rocks and its implications for the lower boundary age of the Nanhua strata in South China. Chinese Science Bulletin 48, 1663-9.

WANG, J. \& LI, Z. X. 2003. History of Neoproterozoic rift basins in South China: implications for Rodinia breakup. Precambrian Research 122, 141-58.

WANG, X. C., LI, X. H., LI, W. X. \& LI, Z. X. 2007. Ca. 825 Ma komatiitic basalts in South China: First evidence for $>1500{ }^{\circ} \mathrm{C}$ mantle melts by a Rodinian mantle plume. Geology 35, 1103-6.

WANG, X. L., ZhOU, J. C., QIU, J. S. \& GAO, J. F. 2004. Geochemistry of the Meso- to Neoproterozoic basic-acid rocks from Hunan Province, South China: implications for the evolution of the western Jiangnan orogen. Precambrian Research 135, 79-103.

WANG, X. L., ZhOU, J. C., QIU, J. S., ZhanG, W. L., LiU, X. M. \& ZHANG, G. L. 2006. LA-ICP-MS U-Pb zircon geochronology of the Neoproterozoic igneous rocks from Northern Guangxi, South China: implications for tectonic evolution. Precambrian Research 145, 111-30.

WATSON, E. B. \& HARRISON, T. M. 1983. Zircon saturation revisited: temperature and composition effects in a variety of crustal magma types. Earth and Planetary Science Letters 64, 295-304.

WILLIAMS, I. S. 1998. U-Th-Pb geochronology by ion microprobe. Applications of Microanalytical Techniques to Understanding Mineralizing Processes. Review of Economic Geology 7, 1-35.

Wingate, M. T. D., CAmpbell, I. H., Compston, W. \& GIBSON, G. M. 1998. Ion microprobe U-Pb ages for Neoproterozoic basaltic magmatism in south-central Australia and implications for the breakup of Rodinia. Precambrian Research 87, 135-59.

WU, R. X., ZHENG, Y. F., WU, Y. B., ZHAO, Z. F., ZHANG, S. B., LIU, X. M. \& WU, F. Y. 2006. Reworking of juvenile crust: Element and isotope evidence from Neoproterozoic granodiorite in South China. Precambrian Research 146, 179-212.

Xiong, X. L., AdAm, J. \& Green, T. H. 2005. Rutile stability and rutile/melt HFSE partitioning during partial melting of hydrous basalt: implications for TTG genesis. Chemical Geology 218, 339-59. 
XIONG, X. L. 2006. Trace element evidence for growth of earth continental crust by melting of rutile-bearing hydrous eclogite. Geology 34, 945-8.

Xiong, X. L., XiA, B., XU, J. F., NiU, H. C. \& XiAO, W. S. 2006. Na depletion in modern adakites via melt/rock reaction within the sub-arc mantle. Chemical Geology 229, 273-92.

Ye, M. F., LI, X. H., LI, W. X., LIU, Y. \& LI, Z. X. 2007. SHRIMP zircon $\mathrm{U}-\mathrm{Pb}$ geochronological and wholerock geochemical evidence for an early Neoproterozoic Sibaoan magmatic arc along the southeastern margin of the Yangtze Block. Gondwana Research 12, 144-56.

ZHANG, L. M., YAN, Y. K. \& YAN, Y. Z. 1991. Microplant species of Guangfeng Group in the NE Jiangxi province: Discovery and significance. Journal of Stratigraphy $\mathbf{1 5}$, 263-9 (in Chinese with English abstract).

ZhANG, S. B., ZHENG, Y. F., WU, Y. B., ZHAO, Z. F., GAO, S. \& WU, F. Y. 2006a. Zircon isotope evidence for $\geq 3.5$ Ga continental crust in the Yangtze craton of China. Precambrian Research 146, 16-34.

ZHANG, S. B., ZHENG, Y. F., WU, Y. B., ZHAO, Z. F., GAO, S., WU, F. Y., 2006b. Zircon U-Pb age and Hf-O isotope evidence for Paleoproterozoic metamorphic event in South China. Precambrian Research 151, 265-88.

ZhaO, J. X., Malcolm, M. T. \& Korsch, R. J. 1994. Characterisation of a plume-related $\sim 800$ Ma magmatic event and its implications for basin formation in centralsouthern Australia. Earth and Planetary Science Letters 121, 349-67.

Zheng, J., Griffin, W. L., O'Reilly, S. Y., Zheng, M., PEARSON, N. \& PAN, Y. 2006. Widespread Archean basement beneath the Yangtze craton. Geology 34, 417-20.

Zhou, C. M., Tucker, R., XiaO, S., Peng, Z., Yuan, X. $\&$ CHEN, Z. 2004. New constraints on the ages of
Neoproterozoic glaciations in south China. Geology 32, 437-40.

ZhOU, H., LI, X. H., WANG, H., LI, J. \& LI, H. 2002as. U$\mathrm{Pb}$ zircon geochronology of basic volcanic rocks within the Yingyangguan Group in Hezhou, Guangxi, and its tectonic implications. Geology Review 48 (Suppl.), 22-5 (in Chinese with English abstract).

Zhou, M. F., Kennedy, A. K., Sun, M., Malpas, J. \& LESHER, C. M. 2002b. Neoproterozoic arc-related mafic intrusions along the northern margin of South China: implications for the accretion of Rodinia. Journal of Geology 110, 611-18.

Zhou, M. F., YAn, D. P., Kennedy, A. K., LI, Y. \& DING, J. 2002c. SHRIMP U-Pb zircon geochronological and geochemical evidence for Neoproterozoic arcmagmatism along the western margin of the Yangtze Block, South China. Earth and Planetary Science Letters 196, 51-67.

Zhou, M. F., MA, Y., YAN, D. P., XIA, X., ZHAO, J. H. \& SuN, M. 2006a. The Yanbian Terrane (Southern Sichuan Province, SW China): A Neoproterozoic arc assemblage in the western margin of the Yangtze Block. Precambrian Research 144, 19-38.

Zhou, M. F., YAN, D. P., WANG, C. L., XIA, X., ZhaO, J. H. \& SUN, M. 2006b. Subduction-related origin of the 750 Ma Xuelongbao adakitic complex (Sichuan Province, China): implications for the tectonic setting of the giant Neoproterozoic magmatic event in South China. Earth and Planetary Science Letters 248, 271-85.

Zhou, J. B., LI, X. H., Ge, W. C. \& LI, Z. X. 2007. Age and origin of Middle Neoproterozoic mafic magmatism in southern Yangtze Block and relevance to the break-up of Rodinia. Gondwana Research 12, 184-97. 